\title{
FONOLOGI BAHASA KANAUMANA KOLANA
}

Lodia Amelia Banik

Universitas Warmadewa

lodiabanik@rocketmail.com

\begin{abstract}
Abstrak
Penelitian ini berjudul Fonologi Bahasa Kanaumana Kolana. Tujuan penelitian ini adalh untuk mendeskripsikan sistem fonem dan proses fonologis dalam bahasa Kanaumana Kolana. Metode yang digunakan dalam penelitian ini adalah metode deskriptif kualitatif. Data yang dikumpulkan berupa bunyi bahasa Kanaumana Kolana yang diperoleh dari hasil wawancara dengan penutur asli bahasa Kanaumana Kolana. Berdasarkan hasil penelitian Bahasa Kanaumana Kolana memiliki enam bunyi vokal yaitu vokal /i/, /u/, /e/, /ع/, /o/, dan /a/, tiga belas bunyi konsonan, yakni konsonan hambat: /p, b, t, d, j, k, g/, konsonan frikatif: /s/, konsonan nasal: /m, n, y/, konsonan likuida atau lateral: /1/, konsonan getar atau trill /r/ dan dua semivokal: /y, w/. Keberadaan keenam vokal, kedua belas bunyi konsonan dan dua bunyi semivokal ini didukung oleh pembuktian dengan menggunakan pasangan minimal pada saat mengidentifikasi bunyi-bunyi fonem tersebut dalam bahasa Kanaumana Kolana. Proses fonologis yang ditemukan dalam bahasa Kanaumana Kolana ada dua, yakni proses pelesapan struktur silabel dan proses pelesapan disertai perubahan struktur silabel berupa perubahan bunyi fonem. Proses fonologis tersebut ditemukan pada saat dua segmen berpadu menjadi satu segmen.
\end{abstract}

Kata kunci: fonem, proses fonologis, pengkaidahan

\begin{abstract}
This research entitled is Phonology of Kanaumana Kolana Language. The purpose of this study was to describe the system of phonemes and describe the phonological processes found in Kanaumana Kolana language. The method used in this research was descriptive qualitative method. Data collected in the form of the sounds of language Kanaumana Kolana obtained from interviews with native speakers Kanaumana Kolana. Based on the research results Language Kanaumana Kolana had six vowels were vowel $/ \mathrm{i} /, \mathrm{L} / \mathrm{/}, \mathrm{le} /, \mid \varepsilon /, / \mathrm{l} /$ and $/ \mathrm{a} /$, thirteen consonant, the consonant resistor: $/ p, b, t$, $d, j, k, g /$ consonant fricatives: / $/$ /, consonant nasal: /m, $n, \mathrm{l} /$, consonant liquid or lateral: / $l$ /, consonant trill / $r$ / and two semi-vowels: / $y, w /$. The existence of the six vowels, twelve consonant and two glides supported by evidence using minimal pairs at the time to identify sounds such phonemes in a language Kanaumana Kolana. Phonological processes found in Kanaumana Kolana language there were two, they were the deletion process syllable structure and deletion processes accompanied by changes in the structure of the syllable form phonemes sound changes. The phonological processes found during the two segments combined into one segment.
\end{abstract}

Keywords: phoneme, phonological process, ruling

\section{PENDAHULUAN}

Di Kelurahan Kolana Utara terdapat tiga bahasa daerah yang digunakan masyarakat yakni bahasa Kanaumana, bahasa Wersing dan bahasa Sawila. Ketiga bahasa ini memiliki perbedaan pada dialek. Secara garis besar bahasa Kanaumana dan Wersing memiliki beberapa persamaan, misalnya pada arti dan struktur kata. Untuk lebih jelasnya, perhatikan contoh leksikon berikut yang menyatakan persamaan dan perbedaan ketiga bahasa tersebut.

Tabel 1

Persamaan dan Perbedaan Bahasa Kanaumana, Sawila, dan Wersing

\begin{tabular}{|l|l|l|l|}
\hline $\begin{array}{l}\text { Bahasa } \\
\text { Kanaumana }\end{array}$ & Bahasa Sawila & Bahasa Wersing & $\begin{array}{l}\text { Bahasa } \\
\text { Indonesia }\end{array}$ \\
\hline gawe gawari & gawe gawari & gawaigawari & $\begin{array}{l}\text { 'pergi lalu } \\
\text { kembali' }\end{array}$ \\
\hline nodu & nadu & nala & 'apa' \\
\hline nanu & nanu & naidu & 'saya' \\
\hline tatuku & tila & lomu & 'bicara' \\
\hline
\end{tabular}


Bahasa Kanaumana atau yang lebih dikenal dengan bahasa Kolana merupakan salah satu bahasa daerah yang digunakan untuk berkomunikasi di wilayah Kelurahan Kolana Utara, Kecamatan Alor Timur, Kabupaten Alor. Sebagai jati diri dari suku Kanaumana, bahasa Kanaumana Kolana harus dilestarikan sehingga budaya dan kearifan lokal tetap terpelihara. Terutama bagi generasi muda, rasa penghargaan yang tinggi terhadap bahasa sendiri perlu ditanamkan dalam benak mereka karena mereka adalah penentu masa depan bangsa ini. Selain itu, untuk membandingkan sistem fonem dari ketiga bahasa daerah yang berada di lingkungan Kelurahan Kolana Utara perlu diadakan pengkajian dalam bahasa Kanaumana Kolana secara mendalam pada kajian Fonologi.

Teori yang relevan digunakan dalam penelitian ini adalah teori fonologi generatif yang dikembangkan oleh Noam Chomsky (1957) dalam bukunya yang berjudul Syntactic Structure (struktur sintaksis) (Warsono, 1991:234). Fonologi generatif (generative phonology) adalah teori fonologi dalam aliran transformasi generatif yang menolak konsep fonem dan menggunakan ciri pembeda sebagai satuan terkecil dan menghubungkan ciri pembeda dan leksikon dengan kaidah-kaidah fonologis. Berkaitan dengan teori yang akan digunakan dalam penelitian ini maka peneliti membatasi ling- kup kajian pada dua hal, yaitu sistem fonem dan proses fonologis yang ditemukan dalam bahasa Kanaumana Kolana.

\section{KONSEP DAN KERANGKA TEORI KONSEP FONEM}

Menurut Muslich (2008: 77), fonem adalah kesatuan terkecil suatu bahasa yang berfungsi membedakan makna. Tuturan merupakan istilah yang berkaitan secara langsung dengan bunyi bahasa. Bunyi bahasa adalah bunyi-bunyi yang dihasilkan oleh alat bicara manusia membentuk tuturan. Bunyi sebagai unsur bahasa adalah bunyibunyi yang membentuk kata. Bunyi-bunyi bahasa itu terdiri dari vokal, konsonan dan diftong.

\section{KONSEP PROSES FONOLOGIS}

Ketika morfem-morfem bergabung untuk membentuk kata, segmen-segmen dari morfem-morfem yang berdekatan mengalami perubahan. Perubahan itulah yang disebut proses fonologis. Terdapat dua faktor yang memicu terjadinya proses fonologis yaitu: 1) adanya persentuhan antarsegmen, antarmorfem, dan antarkata; 2) faktor di luar bahasa (eksternal linguistik) misalnya, sosial dan geografis. Odden (2005:134) memberikan contoh proses fonologis dalam bahasa Inggris yang diakibatkan persentuhan antarmorfem, misalnya bunyi $[\mathrm{k}]$ pada bentuk-bentuk electric, critic, fabatic, dan mystic menjadi [s] apabila bentuk-bentuk itu bersentuhan dengan morfem yang di- 
awali [i] seperti electricity, criticism, fabaticism, dan mysticism. Berkaitan dengan faktor eksternal, Suparwa (2007) dalam Linguistika memberikan contoh proses fonologis dalam bahasa Melayu Loloan Bali yang disebabkan oleh faktor sosial pada pemakaian kata preposisi $k e$ 'ke' berikut ini.

Kulu-kilir an kerjaan kau. [kulu-kilIr an k'rjaan kau] 'Ke utara-selatan (jalan-jalan) saja pekerjaan kamu'

Rangkale die pegi kulu. [raNkale diy' p'gi kulu] 'Barangkali di pergi ke utara'

Dua kalimat di atas menunjukkan pemakaian kata kulu [kulu] 'ke utara' dan kilir [kilIr] 'ke selatan' dalam bahasa Melayu Loloan Bali. Selain bentuk kulu [kulu] yang berarti 'ke utara' dipakai juga bentuk ke ulu [ $\left.k^{\prime} u l u\right]$ dengan arti yang sama, yaitu 'ke utara'. Kata kulu [kulu] 'ke utara' digunakan dalam pemakaian bahasa Melayu Loloan yang biasa (normal). Sementara itu, bentuk ke ulu [ $k^{\prime}$ ulu] 'ke utara' dipakai dalam suasana pemakaian bahasa yang pelan dan cenderung sopan, seperti berbicara dengan orang tua. Pemakaian bahasa biasa/ normal dalam hal ini dimaksudkan sebagai pemakaian bahasa yang akrab (tidak tercermin adanya tinggi-rendah berbahasa), seperti berbicara dengan teman dalam situasi akrab.

\section{KERANGKA TEORI}

\section{FONOLOGI GENERATIF}

Fonologi generatif adalah teori fonologi dalam aliran transformasi generatif yang menolak konsep fonem dan memperlakukan ciri pembeda sebagai satuan terkecil dan menghubungkan ciri pembeda dan leksikon dengan kaidah-kaidah fonologis. Fonologi generatif pada mulanya dikembangkan sebagai aspek fonologikal dari sesuatu yang pada mulanya akan disebut sebagai teori gramatika terpadu atau tergabung yang sisi sintaktiknya pertama-tama ditonjolkan oleh Syntactic Structure (struktur sintaksis) oleh Chomsky (1957) (Warsono, 1991:234).

Kaidah atau pengkaidahan dapat dikatakan sebagai ciri utama dari analisis fonologi generatif. Menurut Schane (terj. 1992: 65-77), ada empat kaidah fonologis dalam fonologi generatif, yaitu: asimilasi, (2) struktur silabel, (3) pelemahan dan penguatan, dan (4) netralisasi.

\section{FITUR-FITUR DISTINGTIF DALAM FONOLOGI GENERATIF}

Fitur distingtif secara garis besar, dapat dibagi menjadi 4 kelompok (lihat Yusuf, 1998: 79-90): (1) ciri utama (konsonantal, silabis, sonoran, dan nasal); (2) ciri distingtif tempat artikulasi (koronal, anterior, high, low, dan back); (3) ciri distingtif cara artikulasi (kontinuan, delayed-releas (del.rel), striden, voice, aspirasi, dan lateral); dan (4) ciri distingtif untuk vokal (round, tense, reduced, dan grave /acute). 
Sedangkan Schane (1992: 28-34), mempunyai pendapat yang berbeda dan membaginya ke dalam 5 kelompok, yaitu: (1) ciriciri kelas utama (silabis, sonoran, konsonantal); (2) ciri cara artikulasi (kontinuan, penglesapan tertunda/del.rel, striden, nasal, lateral); (3) ciri daerah artikulasi (anterior, koronal); (4) ciri batang lidah dan bentuk bibir (tinggi, rendah, belakang, bulat); dan (5) ciri tambahan (tegang, bersuara, aspirasi, glotalisasi).

\section{PEMBAHASAN}

\section{FONEM VOKAL DALAM BAHASA} KANAUMANA KOLANA

Vokal adalah fonem yang dihasilkan alat ucap dengan menggerakkan udara keluar tanpa hambatan. Berdasarkan pada posisi lidah, tinggi-rendahnya lidah, maju mundurnya lidah, dan strukturnya, vokal dalam bahasa Kanaumana Kolana dapat digambarkan dalam tabel berikut ini.

Tabel 2

Vokal dalam bahasa Kanaumana Kolana

\begin{tabular}{|l|l|l|l|l|l|}
\hline & Depan & Tengah & \multicolumn{2}{|l|}{ Belakang } & \multirow{2}{*}{ Struktur } \\
\cline { 2 - 5 } & Tak Bulat & Tak bulat & Bulat & Netral & \\
\hline Tinggi & $\mathrm{i}$ & & & $\mathrm{u}$ & $\begin{array}{l}\text { Tertutup } \\
\text { Semi-Tertutup }\end{array}$ \\
\hline Madya & $\mathrm{e}$ & $\varepsilon$ & & $\mathrm{o}$ & Semi-terbuka \\
\hline Rendah & & $\mathrm{a}$ & & & Terbuka \\
\hline
\end{tabular}

Tabel di atas menunjukkan bahwa dalam bahasa Kanaumana Kolana terdapat enam bunyi vokal. Berdasarkan tinggi-rendahnya lidah, vokal /i/ dan /u/ merupakan vokal tinggi, vokal /e/, / / / dan /o/ termasuk dalam vokal madya sedangkan vokal /a/ termasuk dalam vokal rendah. Berdasarkan majumundurnya lidah, vokal /i/, /e/ termasuk vokal depan, vokal /E/, dan /a/ termasuk dalam vokal tengah, sedangkan vokal /u/ dan /o/ termasuk vokal belakang. Berdasarkan posisi bibir, vokal bulat dalam bahasa Kanaumana Kolana adalah /u/ dan /o/ sedangkan vokal tak bulat yaitu /a/, /i/, /e/ dan $/ \varepsilon /$. Berdasarkan strukturnya, vokal /i/ dan /u/ merupakan vokal tertutup, vokal /e/ dan /o/ termasuk vokal semi-tertutup, vokal /E/ dan /o/ termasuk vokal semiterbuka, dan vokal /a/ termasuk vokal terbuka.

\section{FONEM KONSONAN DALAM}

\section{BAHASA KANAUMANA KOLANA}

Konsonan adalah bunyi ujaran akibat adanya udara yang keluar dari paru-paru mendapatkan hambatan atau halangan. Berdasarkan cara hambat (cara artikulasi) atau tempat hambatan (tempat artikulasi), strukturnya, dan bergetarnya pita suara, konsonan dalam bahasa Kanaumana Kolana dapat digambarkan dalam tabel berikut ini. 
Tabel 3

Bagan Konsonan dalam bahasa Kanaumana Kolana

\begin{tabular}{|c|c|c|c|c|c|c|c|c|c|}
\hline & $\begin{array}{l}\text { Bila- } \\
\text { bial }\end{array}$ & $\begin{array}{l}\text { Labio } \\
- \\
\text { denta } \\
1 \\
\end{array}$ & $\begin{array}{l}\text { Dental \& } \\
\text { Alveolar }\end{array}$ & $\begin{array}{l}\text { Retro } \\
\text {-fleks }\end{array}$ & $\begin{array}{l}\text { Palato- } \\
\text { Alveola } \\
\text { r }\end{array}$ & Palatal & Velar & Uvular & Glotal \\
\hline Hambat & $\mathrm{p} \quad \mathrm{b}$ & & $\mathrm{t}$ & & $\mathrm{j}$ & & $\begin{array}{ll}\mathrm{k} & \mathrm{g} \\
\end{array}$ & & \\
\hline Nasal & $\mathrm{m}$ & & $\mathrm{n}$ & & & & $\mathrm{y}$ & & \\
\hline Frikatif & & & $\mathrm{S}$ & & & & & & \\
\hline \multicolumn{10}{|l|}{ Afrikat } \\
\hline Semivokal & & & & & & $\mathrm{y}$ & W & & \\
\hline Lateral & & & 1 & & & & & & \\
\hline Tril & & & $\mathrm{r}$ & & & & & & \\
\hline Flap & & & & & & & & & \\
\hline
\end{tabular}

Tabel di atas menunjukkan bahwa dalam bahasa Kanaumana terdapat tigabelas konsonan dan dua semivokal. Berdasarkan cara hambat (cara artikulasi) atau tempat hambatan (tempat artikulasi), ketigabelas konsonan tersebut menempati posisi sebagai berikut, konsonan hambat: /p, b, t, d, j k, g/, konsonan frikatif: /s/, konsonan nasal: /m, n, y/, konsonan likuida atau lateral: /1/, konsonan getar atau trill $/ \mathrm{r} /$ dan semivokal: $/ \mathrm{y}$, w/. Berdasarkan strukturnya, konsonan /p, b, $\mathrm{m} /$ termasuk dalam konsonan bilabial. Konsonan /j/ termasuk dalam konsonan palato-alveolar. Konsonan /t, d, n, s, 1, r/ termasuk dalam konsonan dental \& alveolar. Semivokal /y/ termasuk dalam palatal. Konsonan $/ \mathrm{k}, \mathrm{g}, \mathrm{y} /$ dan semivokal /w/ termasuk dalam velar Berdasarkan posisi pita suara atau bergetar tidaknya pita suara, konsonan dalam bahasa Kanaumana Kolana yang termasuk dalam konsonan bersuara, yakni /b, d, j, g, m, n, y, r, l/ dan semivokal /y, w/. Sedangkan yang tak bersuara, yaitu konso$\operatorname{nan} / \mathrm{p}, \mathrm{t}, \mathrm{k}, \mathrm{s} /$.
PEMBUKTIAN FONEM VOKAL DAN KONSONAN DALAM BAHASA KANAUMANA KOLANA

Bunyi-bunyi bahasa yang sudah disebutkan di atas belum tentu semuanya merupakan fonem. Untuk mengetahui apakah bunyi-bunyi tersebut adalah fonem, maka perlu dibuktikan melalui pasangan minimal. Pasangan minimal merujuk pada setiap dua kata yang hanya dibedakan oleh suara berbeda dalam satu posisi. Dari pasangan minimal berikut dapat dibuktikan bahwa bahasa Kanaumana Kolana memiliki enam vokal fonem vokal, tiga belas konsonan dan dua semivokal.

Tabel 4

Pasangan Minimal Bunyi Vokal Fonem Vokal dan Konsonan dalam Bahasa Kanaumana Kolana

\begin{tabular}{|c|c|c|}
\hline Fonem & \multicolumn{2}{|c|}{ Contoh Kata } \\
\hline$/ \mathbf{a} / \operatorname{dan} / \mathbf{i} /$ & {$[$ apa $a]$} & [api] \\
\hline$/ \mathbf{a} / \mathbf{d a n} / \mathbf{u} /{ }^{\prime}$ & $\begin{array}{l}\text { bawaha } \\
\text { juana }]\end{array}$ & $\begin{array}{l}\text { [Lami } \\
\text { [yamus }]\end{array}$ \\
\hline$/ \mathrm{i} / \operatorname{dan} / \mathbf{w}^{\prime}$ & [gani $]$ & {$[\operatorname{gan} x t]$} \\
\hline$/ \mathbf{a} / \mathbf{d a n} / \mathbf{e}^{\prime}$ & 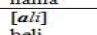 & {$\left[a z_{i}\right]$} \\
\hline$/ \mathrm{a} / \mathrm{dan} / \mathrm{o} /$ & [siz $a]$ & [site ] \\
\hline$\sqrt{ } / \varepsilon^{\prime} / \mathrm{dan} / \mathrm{E}^{\prime} /$ & $\begin{array}{l}\text { putih } \\
{[\mathrm{ms}]}\end{array}$ & $\begin{array}{l}\text { apung } \\
{[\mathrm{ss \varepsilon ]}}\end{array}$ \\
\hline$/ \mathbf{b} / d \operatorname{dan} / \mathbf{d}^{/} /$ & $\begin{array}{l}\text { atang } \\
\text { [gaboka] }\end{array}$ & [gadoka] \\
\hline$/ \operatorname{tt} / \mathbf{d a n} / \mathrm{g} /$ & $\begin{array}{l}\text { dorong } \\
{\left[\begin{array}{l}\text { trami }] \\
\text { barat }\end{array}\right.}\end{array}$ & [ganin $]$ \\
\hline$/ \mathrm{k} / \mathrm{dan} / \mathrm{V}$ & $\begin{array}{l}\text { barat } \\
\text { [sike }]\end{array}$ & $\frac{\text { nama }}{[\text { site }]}$ \\
\hline $\mathbf{p}^{\prime / d \mathbf{a n}} / \mathbf{n} /$ & $\frac{\text { panah }}{[\text { tappi }]}$ & $\frac{\text { apung }}{[\operatorname{tanin}]}$ \\
\hline$/ \mathrm{w} / / \operatorname{dan} / \mathrm{y}^{\prime} /$ & $\begin{array}{l}\text { benar } \\
{\left[\begin{array}{l}\text { [warara }] \\
\text { batu }\end{array}\right.}\end{array}$ & $\begin{array}{l}\text { barat } \\
\text { [yraras }] \\
\text { batas }\end{array}$ \\
\hline$/ \mathbf{r} / \mathbf{d a n} / \mathbf{I}$ & {$[$ [wara] } & [wala] \\
\hline$/ \mathbf{m} / \operatorname{dan} / \mathbf{s} /$ & {$[\mathrm{ms}]$} & {$[s s]$} \\
\hline
\end{tabular}


PROSES FONOLOGIS DALAM BAHA-

\section{SA KANAUMANA KOLANA}

Dalam bahasa Kanaumana Kolana, proses fonologis ditemukan pada saat dua segmen berpadu menjadi satu segmen. Misalnya natakasara 'saya punya kepala' merupakan segmen yang terbentuk dari kata / nanu/'saya' dan /takasara/ 'kepala'.

\section{PROSES PELESAPAN STRUKTUR}

\section{SILABEL}

$\begin{array}{lll}\text { Data } 1 & & \\ \text { Inanul + Itakasaral } & \text { [natakasara] } & \text { 'saya punya kepala' } \\ \text { Inanul + Itakalakal } & \text { [natakalaka] } & \text { 'saya punya rambut' } \\ \text { Iganul + Itakasaral } & \text { [gatakasara] } & \text { 'dia punyakepala' } \\ \text { Iganul + Itakalakal } & \text { [gatakalaka] } & \text { 'dia punyarambut' }\end{array}$

Berdasarkan data di atas, proses fonologis terjadi antara dua morfem yang berbeda. Data di atas merupakan proses fonologis berupa pelesapan struktur silabel. Suku kata -nu mengalami pelesapan jika berada di lingkungan suku kata ta-. Berikut adalah kaidah fonologisnya:

\begin{tabular}{|c|c|c|}
\hline $\ln /$ & $\mid \mathrm{ul}$ & $|t|$ \\
\hline +kons & tsil & tkons \\
\hline tson & +ting & -son \\
\hline tbersuara & -rend & - bersuara \\
\hline tnasal & $\begin{array}{l}\text { +bulat } \\
\text { +blkg }\end{array}$ & -nasal \\
\hline
\end{tabular}

Kaidah di atas menyatakan bahwa bunyi konsonan /n/ dan bunyi vokal /u/ mengalami pelesapan jika bunyi konsonan /n/ berada di tengah kata yang sebelum bunyi tersebut berupa bunyi vokal yang mempunyai fitur $[+$ sil, +rend, +bersuara] dan diikuti juga bunyi vokal yang mempunyai fitur [+sil, +ting, -rend, +bulat, +blkg]. Sedangkan bunyi vokal /u/ mengalami pele- sapan jika bunyi tersebut berada di akhir kata yang sebelum bunyi tersebut berupa bunyi konsonan yang mempunyai fitur [+kons, +ant, +bersuara, +nasal].

Dari data di atas dapat dilihat bahwa pelesapan bunyi /n/ dan /u/ di akhir kata pertama diikuti oleh kata kedua yang dimulai dengan bunyi konsonan /t/ yang mempunyai fitur [+kons, -son, -bersuara, -nasal] dan diikuti bunyi vokal /a/ yang berfitur [+sil, ting. +rend, -bulat, -blkg]. Penghilangan bunyi tersebut bertujuan untuk menyederhanakan jumlah silabel dalam sebuah kata dari yang dua kata menjadi satu kata, sehingga kata tersebut mudah untuk dilafalkan.

Data 2

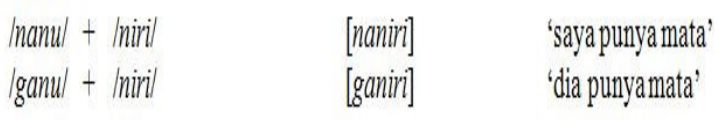

Berdasarkan data di atas, proses fonologis terjadi antara dua morfem yang berbeda. Adapun kaidah untuk menyatakan pelesapan tersebut adalah sebagai berikut:

\begin{tabular}{|c|c|c|c|}
\hline$|\mathrm{n}|$ & $/ \mathrm{u} /$ & & |n] \\
\hline +kons & +sil & & +kons \\
\hline tson & +bulat & & tson \\
\hline bersuara & -depan & $\theta$ & tbersuara \\
\hline nasal & +blkg & & tnasal \\
\hline
\end{tabular}

Kaidah di atas menyatakan bahwa bunyi konsonan /n/ dan bunyi vokal /u/ mengalami pelesapan jika bunyi konsonan /n/ berada di tengah kata yang sebelum bunyi tersebut berupa bunyi vokal yang mempunyai fitur [+sil, +rend, +bersuara] dan diikuti juga bunyi vokal yang mempunyai fitur 
[+sil, +bulat, -depan, +blkg]. Sedangkan bunyi vokal /u/ mengalami pelesapan jika bunyi tersebut berada di akhir kata yang sebelum bunyi tersebut berupa bunyi konsonan yang mempunyai fitur [+kons, + +son, +bersuara, +nasal].

Dari data di atas dapat dilihat bahwa pelesapan bunyi /n/ dan $/ \mathrm{u} /$ di akhir kata pertama diikuti oleh kata kedua yang dimulai dengan bunyi konsonan / $\mathrm{n} /$ yang mempunyai fitur [+kons, +son, +bersuara, +nasal] dan diikuti bunyi vokal /i/ yang berfitur [+sil, -bulat, +depan, -blkg]. Penghilangan bunyi tersebut bertujuan untuk menyederhanakan jumlah silabel dalam sebuah kata dari yang dua kata menjadi satu kata, sehingga kata tersebut mudah untuk dilafalkan.

\section{Data 3}

$$
\begin{array}{rrr}
\text { a. Inanul + Imasing/ } & \text { [namasing] } & \text { 'sayalapar' } \\
\text { Iganul + Imasing/ } & \text { [gamasing] } & \text { 'dia lapar' }
\end{array}
$$

Kaidah fonologisnya:

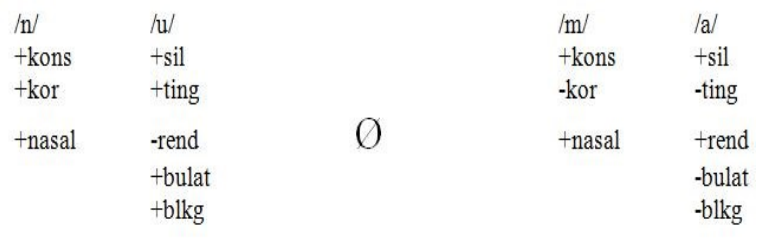

Kaidah di atas menyatakan bahwa bunyi konsonan $/ \mathrm{n} /$ dan bunyi vokal /u/ mengalami pelesapan jika bunyi konsonan /n/ berada di tengah kata yang sebelum bunyi tersebut berupa bunyi vokal yang mempunyai fitur [+sil, +rend, +bersuara] dan diikuti juga bunyi vokal yang mempunyai fitur [+sil, +ting, -rend, +bulat, +blkg]. Se- dangkan bunyi vokal /u/ mengalami pelesapan jika bunyi tersebut berada di akhir kata yang sebelum bunyi tersebut berupa bunyi konsonan yang mempunyai fitur [+kons, +kor, +nasal].

Dari data di atas dapat dilihat bahwa pelesapan bunyi $/ \mathrm{n} /$ dan $/ \mathrm{u} /$ di akhir kata pertama diikuti oleh kata kedua yang dimulai dengan bunyi konsonan $/ \mathrm{m} /$ yang mempunyai fitur [+kons, -kor, +nasal] dan diikuti bunyi vokal /a/ yang berfitur [+sil, -ting, +rend, -bulat, -blkg].

$\begin{array}{lll}\text { b. Inomul }+ \text { Imingil } & \text { [namingi] } & \text { 'sayapunyahahidung' } \\ \text { lgamul }+ \text { Imingil } & \text { [gamingi] } & \text { 'diapunyahidung' }\end{array}$

Kaidah fonologisnya:

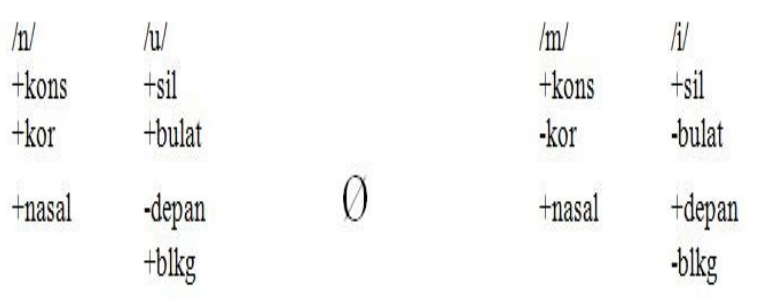

Kaidah di atas menyatakan bahwa bunyi konsonan /n/ dan bunyi vokal /u/ mengalami pelesapan jika bunyi konsonan /n/ berada di tengah kata yang sebelum bunyi tersebut berupa bunyi vokal yang mempunyai fitur [+sil, +rend, +bersuara] dan diikuti juga bunyi vokal yang mempunyai fitur [+sil, +bulat, -depan, +blkg]. Sedangkan bunyi vokal $/ \mathrm{u} /$ mengalami pelesapan jika bunyi tersebut berada di akhir kata yang sebelum bunyi tersebut berupa bunyi konsonan yang mempunyai fitur [+kons, +kor, +nasal]. 
Dari data di atas dapat dilihat bahwa pelesapan bunyi $/ \mathrm{n} /$ dan $/ \mathrm{u} /$ di akhir kata pertama diikuti oleh kata kedua yang dimulai dengan bunyi konsonan /m/ yang mempunyai fitur [+kons, -kor, +nasal] dan diikuti bunyi vokal /i/ yang berfitur [+sil, -bulat, +depan, -blkg].

\begin{tabular}{|c|c|}
\hline c. Inanul + |muri| & [namuri] \\
\hline Iganul + Imuril & [gamuri] \\
\hline
\end{tabular}

Kaidah fonologisnya:

\begin{tabular}{|c|c|c|c|}
\hline In] & $|u|$ & & $\mathrm{lm} /$ \\
\hline thons & tsil & & tkons \\
\hline +kor & tbulat & & -kor \\
\hline tnasal & $\begin{array}{l}\text {-depan } \\
\text {-blkg }\end{array}$ & $\emptyset$ & tnasal \\
\hline
\end{tabular}

Kaidah di atas menyatakan bahwa bunyi konsonan /n/ dan bunyi vokal /u/ mengalami pelesapan jika bunyi konsonan /n/ berada di tengah kata yang sebelum bunyi tersebut berupa bunyi vokal yang mempunyai fitur [+sil, +rend, +bersuara] dan diikuti juga bunyi vokal yang mempunyai fitur [+sil, +bulat, -depan, +blkg]. Sedangkan bunyi vokal /u/ mengalami pelesapan jika bunyi tersebut berada di akhir kata yang sebelum bunyi tersebut berupa bunyi konsonan yang mempunyai fitur [+kons, +kor, + nasal].

Dari data di atas dapat dilihat bahwa pelesapan bunyi /n/ dan /u/ di akhir kata pertama diikuti oleh kata kedua yang dimulai dengan bunyi konsonan $/ \mathrm{m} /$ yang mempunyai fitur [+kons, -kor, +nasal] dan diikuti bunyi vokal /u/ yang berfitur [+sil, +bulat, depan, + blkg].
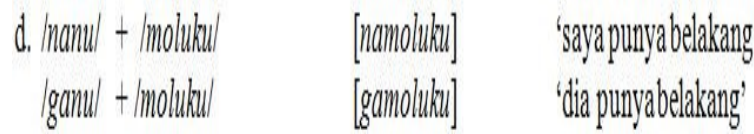

Kaidah fonologisnya:

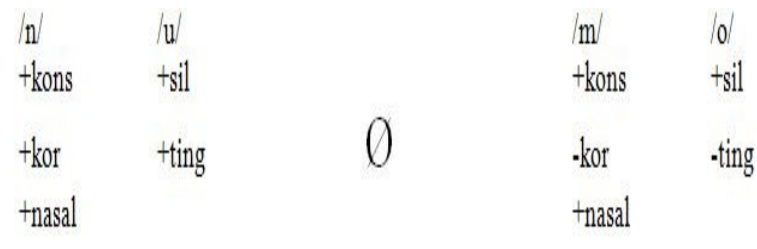

Kaidah di atas menyatakan bahwa bunyi konsonan /n/ dan bunyi vokal /u/ mengalami pelesapan jika bunyi konsonan /n/ berada di tengah kata yang sebelum bunyi tersebut berupa bunyi vokal yang mempunyai fitur [+sil, +rend, +bersuara] dan diikuti juga bunyi vokal yang mempunyai fitur [+sil, +ting]. Sedangkan bunyi vokal /u/ mengalami pelesapan jika bunyi tersebut berada di akhir kata yang sebelum bunyi tersebut berupa bunyi konsonan yang mempunyai fitur [+kons, +kor, +nasal].

Dari data di atas dapat dilihat bahwa pelesapan bunyi /n/ dan /u/ di akhir kata pertama diikuti oleh kata kedua yang dimulai dengan bunyi konsonan /m/ yang mempunyai fitur [+kons, -kor, +nasal] dan diikuti bunyi vokal /o/ yang berfitur [+sil, -ting].

\section{Data 4}

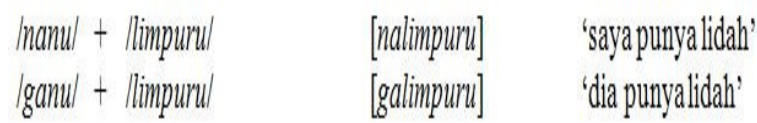

Kaidah fonologisnya:

\begin{tabular}{|c|c|c|c|}
\hline |n| & $|u|$ & & II \\
\hline +kons & tsil & & +kons \\
\hline +nasal & tbulat & & -nasal \\
\hline -la & -depan & $\theta$ & that \\
\hline & tblkg & & \\
\hline
\end{tabular}


Kaidah di atas menyatakan bahwa bunyi konsonan $/ \mathrm{n} /$ dan bunyi vokal /u/ mengalami pelesapan jika bunyi konsonan /n/ berada di tengah kata yang sebelum bunyi tersebut berupa bunyi vokal yang mempunyai fitur [+sil, +rend, +bersuara] dan diikuti juga bunyi vokal yang mempunyai fitur [+sil, +bulat, -depan, +blkg]. Sedangkan bunyi vokal /u/ mengalami pelesapan jika bunyi tersebut berada di akhir kata yang sebelum bunyi tersebut berupa bunyi konsonan yang mempunyai fitur [+kons, +nasal, -lat].

Dari data di atas dapat dilihat bahwa pelesapan bunyi /n/ dan /u/ di akhir kata pertama diikuti oleh kata kedua yang dimulai dengan bunyi konsonan /1/ yang mempunyai fitur [+kons, -nasal, +lat] dan diikuti bunyi vokal /i/ yang berfitur [+sil, -bulat, +depan, -blkg].

\section{Datas}
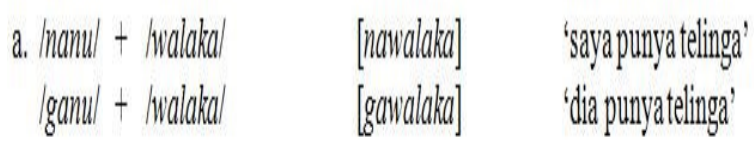

Kaidah fonologisnya:

\begin{tabular}{|c|c|c|}
\hline$|\mathrm{n}|$ & $\mid \mathrm{ul} /$ & $/ \mathrm{w} /$ \\
\hline -ting & tsil & + ting \\
\hline -blkg & + ting & tblkg \\
\hline tant & & -ant \\
\hline tkor & tbulat & -kor \\
\hline $\begin{array}{l}\text {-nasal } \\
\text {-bulat }\end{array}$ & tblkg & $\begin{array}{l}\text {-nasal } \\
\text { +bulat }\end{array}$ \\
\hline
\end{tabular}

Kaidah di atas menyatakan bahwa bunyi konsonan /n/ dan bunyi vokal /u/ mengalami pelesapan jika bunyi konsonan /n/ berada di tengah kata yang sebelum bunyi tersebut berupa bunyi vokal yang mempunyai fitur [+sil, +rend, +bersuara] dan diikuti juga bunyi vokal yang mempunyai fitur $[+$ sil, +ting, -rend, +bulat, +blkg]. Sedangkan bunyi vokal /u/ mengalami pelesapan jika bunyi tersebut berada di akhir kata yang sebelum bunyi tersebut berupa bunyi konsonan yang mempunyai fitur [-ting, -blkg, +ant, +kor, +nasal, -bulat].

Dari data di atas dapat dilihat bahwa pelesapan bunyi /n/ dan /u/ di akhir kata pertama diikuti oleh kata kedua yang dimulai dengan bunyi konsonan /w/ yang mempunyai fitur [+ting, +blkg, -ant, -kor, -nasal, +bulat] dan diikuti bunyi vokal /a/ yang berfitur [+sil, -ting, +rend, -bulat, -blkg].
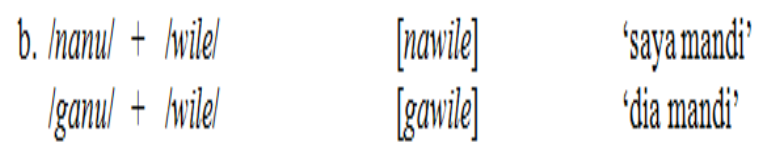

Kaidah fonologisnya:

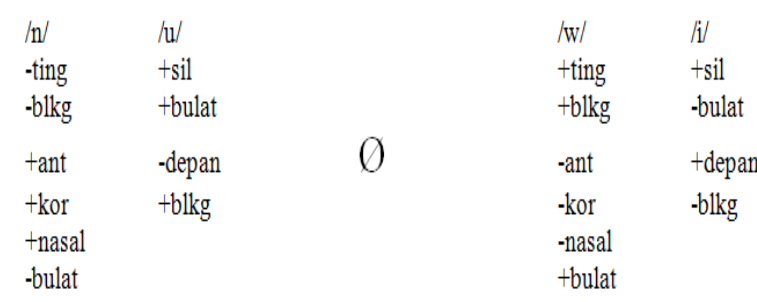

Kaidah di atas menyatakan bahwa bunyi konsonan /n/ dan bunyi vokal /u/ mengalami pelesapan jika bunyi konsonan /n/ berada di tengah kata yang sebelum bunyi tersebut berupa bunyi vokal yang mempunyai fitur [+sil, +rend, +bersuara] dan diikuti juga bunyi vokal yang mempunyai fitur [+sil, +bulat, -depan, +blkg]. Sedangkan bunyi vokal /u/ mengalami pelesapan jika bunyi tersebut berada di akhir kata yang sebelum bunyi tersebut berupa bunyi kon- 
sonan yang mempunyai fitur [-ting, -blkg, +ant, +kor, +nasal, -bulat].

Dari data di atas dapat dilihat bahwa pelesapan bunyi /n/ dan /u/ di akhir kata pertama diikuti oleh kata kedua yang dimulai dengan bunyi konsonan /w/ yang mempunyai fitur [+ting, +blkg, -ant, -kor, -nasal, +bulat] dan diikuti bunyi vokal /i/ yang berfitur [+sil, -bulat, +depan, -blkg].
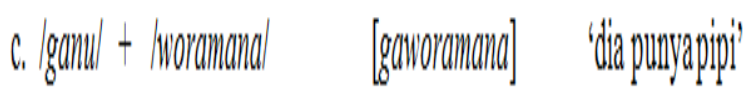

Kaidah fonologisnya:

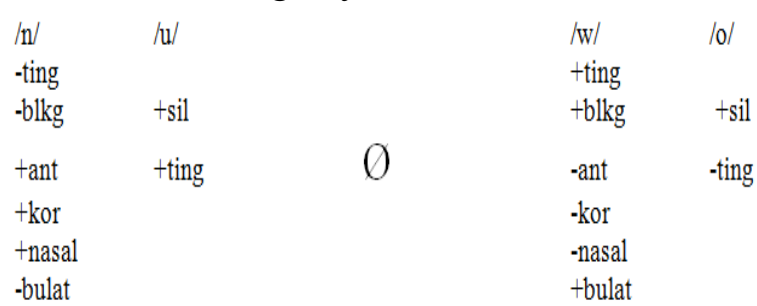

Kaidah di atas menyatakan bahwa bunyi konsonan /n/ dan bunyi vokal /u/ mengalami pelesapan jika bunyi konsonan /n/ berada di tengah kata yang sebelum bunyi tersebut berupa bunyi vokal yang mempunyai fitur [+sil, +rend, +bersuara] dan diikuti juga bunyi vokal yang mempunyai fitur $[+$ sil, +ting]. Sedangkan bunyi vokal /u/ mengalami pelesapan jika bunyi tersebut berada di akhir kata yang sebelum bunyi tersebut berupa bunyi konsonan yang mempunyai fitur [-ting, -blkg, +ant, +kor, +nasal, bulat].

Dari data di atas dapat dilihat bahwa pelesapan bunyi /n/ dan /u/ di akhir kata pertama diikuti oleh kata kedua yang dimulai dengan bunyi konsonan /w/ yang mempunyai fitur [+ting, +blkg, -ant, -kor, -nasal, +bulat] dan diikuti bunyi vokal /o/ yang berfitur [+sil, -ting].

\section{PROSES PELESAPAN DISERTAI PERUBAHAN STRUKTUR SILABEL}

Data 1

Inanul + Idosal [nidosa] 'saya punya dosa'

Adapun kaidah untuk menyatakan pelesapan dan perubahan tersebut adalah sebagai berikut:

Proses pelesapan:

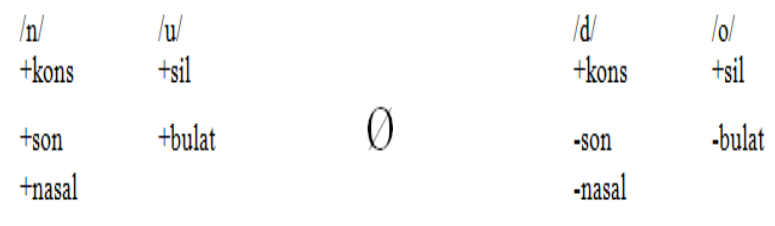

Proses perubahan:

$\begin{array}{lll}|a| & |i| & \mid d / \\ \text { tsil } & \text { +sil } & \text { +kons } \\ \text {-ting } & \text { ting } & \text {-son } \\ \text { trend } & \text {-rend } & \text {-rend } \\ \text {-depan } & \text { tdepan } & \text { tant } \\ & & \text { tkor }\end{array}$

Kaidah di atas menyatakan bahwa bunyi konsonan /n/ dan bunyi vokal/u/ mengalami pelesapan dan perubahan pada bunyi vokal /a/ menjadi bunyi vokal /i/. Bunyi konsonan /n/ dan bunyi vokal /u/ mengalami pelesapan jika bunyi konsonan /n/ berada di tengah kata yang sebelum bunyi tersebut berupa bunyi vokal yang mempunyai fitur [+sil, +rend, +bersuara] dan diikuti juga bunyi vokal yang mempunyai fitur [+sil, +ting]. Sedangkan bunyi vokal /u/ mengalami pelesapan jika bunyi tersebut berada di akhir kata yang sebelum bunyi tersebut berupa bunyi konsonan yang 
mempunyai fitur [+kons, +son, +nasal]. Pelesapan bunyi /n/ dan /u/ di akhir kata pertama diikuti oleh kata kedua yang dimulai dengan bunyi konsonan /s/ yang mempunyai fitur [+kons, -son, -nasal] dan diikuti bunyi vokal /i/ yang berfitur [+sil, -ting].

Dari data di atas dapat dilihat bahwa perubahan bunyi vokal /a/ yang mempunyai fitur [+sil, -ting, +rend, -depan] menjadi bunyi vokal /i/ yang berfitur [+sil, +ting, rend, +depan] terjadi apabila bunyi vokal / a/ berada di lingkungan bunyi konsonan /d/ yang mempunyai fitur [+kons, -son, -rend, tant, +kor].

\section{Data 2}

$$
\begin{array}{lll}
\text { Inanul }+\mid \text { kisil } & \text { [nikisi] } & \text { 'saya punyakaki' } \\
\mid \text { ganul }+\mid \text { kisil } & \text { [gikisi }] & \text { 'dia punyakaki' }
\end{array}
$$

Adapun kaidah untuk menyatakan pelesapan dan perubahan tersebut adalah sebagai berikut:

Proses pelesapan

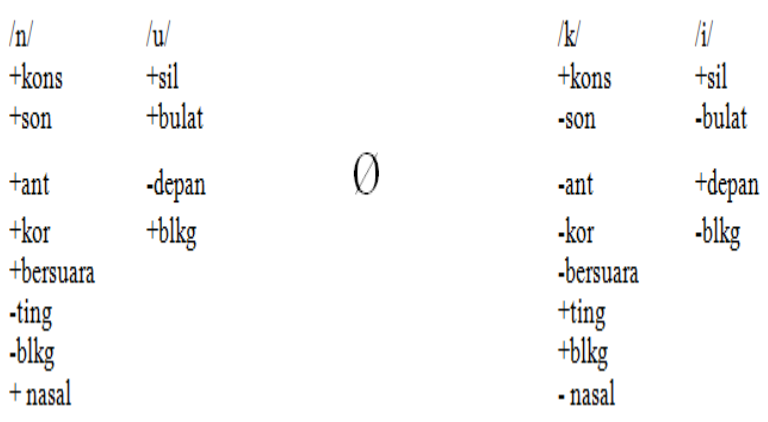

Proses perubahan:

$\begin{array}{lll}\text { /a/ } & \text { |i } / & \\ \text { +sil } & \text { +sil } & \text { +kons } \\ \text {-ting } & \text { +ting } & \text {-son } \\ \text { +rend } & \text {-rend } & \text { +ting } \\ \text {-depan } & \text { +depan } & \text { +blkg } \\ & & \text {-rend } \\ & & \text {-bersuara }\end{array}$

Kaidah di atas menyatakan bahwa bunyi konsonan /n/ dan bunyi vokal /u/ mengalami pelesapan dan bunyi vokal /a/ mengalami perubahan menjadi bunyi vokal/i/. Bunyi konsonan /n/ dan bunyi vokal /u/ mengalami pelesapan jika bunyi konsonan /n/ berada di tengah kata yang sebelum bunyi tersebut berupa bunyi vokal yang mempunyai fitur [+sil, +rend, +bersuara] dan diikuti juga bunyi vokal yang mempunyai fitur [+sil, +blkg, +bulat, -depan]. Sedangkan bunyi vokal /u/ mengalami pelesapan jika bunyi tersebut berada di akhir kata yang sebelum bunyi tersebut berupa bunyi konsonan yang mempunyai fitur [+kons, +son, ting, -blkg, +ant, +kor, +bersuara, +nasal]. Pelesapan bunyi /n/ dan /u/ di akhir kata pertama diikuti oleh kata kedua yang dimulai dengan bunyi konsonan /k/ yang mempunyai fitur [+kons, -son, +ting, +blkg, -ant, -kor, -bersuara, -nasal] dan diikuti bunyi vokal /i/ yang berfitur [+sil, -blkg, bulat, +depan].

Dari data di atas dapat dilihat bahwa perubahan bunyi vokal /a/ yang mempunyai fitur [+sil, -ting, +rend, -depan] menjadi bunyi vokal /i/ yang berfitur [+sil, +ting, rend, +depan] terjadi apabila bunyi vokal /a/ berada di lingkungan bunyi konsonan /k/ yang mempunyai fitur [+kons, -son, +ting, +blkg, -rend, -bersuara].

Data 3

Inanul $+\mid$ sil [nisi] 'Sayapunyabadan' Iganul + |sil [gisi] 'dia punyabadan' 
Adapun kaidah untuk menyatakan pelesapan dan perubahan tersebut adalah sebagai berikut:

Proses pelesapan:

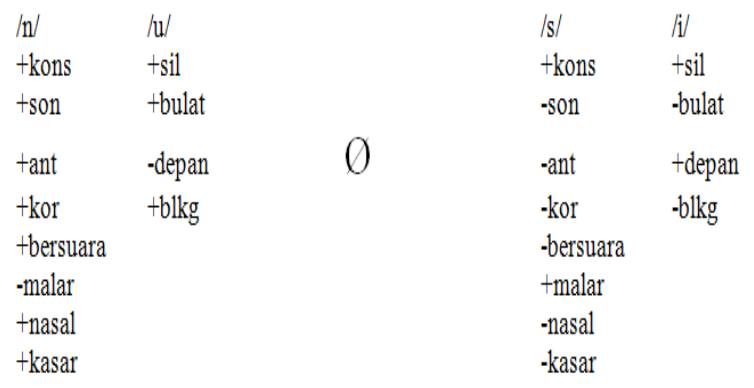

Proses perubahan:

$\begin{array}{lll}\text { la/ } & \text { li/ } & \text { /s/ } \\ \text { +sil } & \text { tsil } & \text { +kons } \\ \text {-ting } & \text { ting } & \text {-son } \\ \text { trend } & \text {-rend } & \text {-rend } \\ \text {-depan } & \text { tepan } & \text {-bersuara } \\ & & \text { +malar } \\ & & \text { tkasar }\end{array}$

Kaidah di atas menyatakan bahwa bunyi konsonan /n/ dan bunyi vokal /u/ mengalami pelesapan dan perubahan pada bunyi vokal /a/ menjadi bunyi vokal /i/. Bunyi konsonan /n/ dan bunyi vokal /u/ mengalami pelesapan jika bunyi konsonan /n/ berada di tengah kata yang sebelum bunyi tersebut berupa bunyi vokal yang mempunyai fitur [+sil, +rend, +bersuara] dan diikuti juga bunyi vokal yang mempunyai fitur [+sil, +bulat, -depan, +blkg]. Sedangkan bunyi vokal /u/ mengalami pelesapan jika bunyi tersebut berada di akhir kata yang sebelum bunyi tersebut berupa bunyi konsonan yang mempunyai fitur [+kons, +son, +ant, +kor, +bersuara, -malar, +nasal, +kasar]. Pelesapan bunyi /n/ dan /u/ di akhir kata pertama diikuti oleh kata kedua yang dimulai dengan bunyi konsonan /s/ yang mempunyai fitur [+kons, -son, -ant, -kor, -bersuara, +malar, -nasal, -kasar] dan diikuti bunyi vokal /i/ yang berfitur [+sil, -bulat, +depan, -blkg].

Dari data di atas dapat dilihat bahwa perubahan bunyi vokal /a/ yang mempunyai fitur [+sil, -ting, +rend, -depan] menjadi bunyi vokal /i/ yang berfitur [+sil, +ting, rend, +depan] terjadi apabila bunyi vokal /a/ berada di lingkungan bunyi konsonan /s/ yang mempunyai fitur [+kons, -son, -rend, bersuara, +malar, +kasar].

\section{KESIMPULAN}

Berdasarkan hasil pembahasan pada babbab sebelumnya maka dapat disimpulkan beberapa hal sebagai berikut.

1. Bahasa Kanaumana Kolana memiliki enam bunyi vokal yaitu vokal /i/, /u/, / e/, /ع/, /o/, dan /a/. Bahasa Kanaumana Kolana memiliki tiga belas bunyi konsonan, yakni konsonan hambat: /p, b, t, d, j, k, g/, konsonan frikatif: /s/, konsonan nasal: /m, n, y/, konsonan likuid atau lateral: /1/, konsonan getar atau trill /r/ dan dua semivokal: /y, w/. Keberadaan keenam bunyi vokal, tiga belas bunyi konsonan dan dua bunyi semivokal ini didukung oleh pembuktian dengan menggunakan pasangan minimal pada saat mengidentifikasi bunyi fonem-fonem tersebut dalam bahasa Kanaumana Kolana. 
2. Proses fonologis dalam bahasa Kanaumana Kolana ditemukan pada saat dua segmen berpadu menjadi satu segmen. Pada proses pelesapan struktur silabel, bunyi bahasa yang lesap bertujuan untuk menyederhanakan jumlah silabel dalam sebuah kata dari yang dua kata menjadi satu kata, sehingga kata tersebut mudah untuk dilafalkan.

\section{UCAPAN TERIMA KASIH}

Penulis mengucapkan terima kasih kepada Dr. Ni Wayan Kasni, M.Hum, selaku Ketua Program Studi Magister Linguistik, sekaligus dosen pembimbing II, atas segala waktu dan tenaganya dalam memberikan bimbingan, arahan, dan masukkan kepada penulis, dan juga kepada Dr. I Wayan Budiarta, S.S., M.Hum selaku Sekretaris Program Studi Magister Linguistik, sekaligus pembimbing $\mathrm{I}$, atas segala dukungan, bimbingan, arahan dan motivasi yang diberikan selama proses studi dan bimbingan kepada penulis dari awal hingga akhir penulisan tesis ini.

\section{DAFTAR PUSTAKA}

Chaer, Abdul. 2009. Fonologi Bahasa Indonesia. Jakarta: Rineka Cipta.

KBBI (tim peny.). 2008. Kamus Besar Bahasa Indonesia. Jakarta: Pusat Bahasa.

Kridalaksana, Harimurti. 2008. Kamus Lingustik. Jakarta: PT Gramedia PustakaUtama.

http://eprints.ums.ac.id/ (diunduh 18 juli 2015)

http://repository.unand.ac.id/(diunduh 18 http://

juli 2015)

Tin-

ta.Linguistik.Fonologi.Struktural.dan

.Generatif.html (diunduh 18 juli 2015)

Budiarta, I Wayan. 2015. Fonologi. Makalah (Disajikan pada Matrikulasi Mahasiswa Baru Angkatan V Program Studi Magister Linguistik Program Pascasarjana Universitas Warmadewa. Selasa, 24 Maret 2015)

Lass, Roger. 1991. Fonologi sebuah pengantar untuk konsep-konsep dasar. Terjemahan Warsono, dkk. Semarang: IKIP Semarang Press.

Moleong, Lexi J. 2007. Metodologi Penelitian Kualitatif. Bandung: PT Remaja Rosda Karya.

Muhammad. 2011. Metode Penelitian Bahasa. Jogjakarta: Ar-ruzz Media.

Mushlich, Mansur. 2008. Fonologi Bahasa Indonesia; Tinjauan Deskriptif Sistembunyi Bahasa Indonesia. Jakarta: Bumi Aksara.

Odden, David. 2005. Introducing Phonology. Cambridge: Cambridge UniversityPress.

Schane, Sanford. 1973. Generative Phonology. New Jersey: PRENTICE-HALL, INC.

Simanjuntak, Mangantar. 1990. Teori Fitur Distingtif Dalam Fonologi Generatif:

Perkembangan dan Penerapannya. Jakarta: Gaya Media Pratama.

Sudaryanto. 2015. Metode dan Aneka Teknik Analisis Bahasa: PengantarPenelitian Wahana Kebudayaan secara Linguistis. Yogyakarta: SanataDharma University Press.

Yusuf, Suhendra. 1998. Fonetik dan Fonologi. Jakarta: PT Gramedia PustakaUtama.

Zen, Abdul malik. 2016. Perubahan Fonologis Kosakata Serapan Sansekerta dalam Bahasa Jawa (Analisis Fitur Distingtif dalam Fonologi Transformasi Generatif) (TESIS).Semarang: Iniversitas 
Diponegoro.

2004. Linguistika, Vol. 14, No. 27, September 2007.

2012. MOZAIK: Jurnal Ilmu Humaniora, Vol. 12 No. 2 Juli-September: hal 122-132.

2013. Proceeding PESAT (Psikologi, Ekonomi, Sastra, Arsitektur \& Teknik Sipil), Vol. 2 Oktober: hal 75-83. Bandung. 